\title{
Change in the relative importance of oestrone and oestradiol synthesis by the rat ovary between fetal and prepubertal stages
}

\author{
J.-P. Weniger and A. Zeis \\ Laboratoire de Zoologie et d'Embryologie expérimentale, Université Louis-Pasteur, \\ 12 rue de l'Université, F-67000 Strasbourg, France
}

\begin{abstract}
Summary. Ovaries of rat fetuses at 20 and 21 days and of neonatal rats at 5 and 14 days were cultured in the presence of $\left[{ }^{3} \mathrm{H}\right]$ testosterone, and the conversion percentages into oestrone $\left(\mathrm{E}_{1}\right)$ and oestradiol $\left(\mathrm{E}_{2}\right)$ were determined by double isotopic dilution combined with recrystallization to constant specific activity. Insignificant in the 20- or 21day-old fetus, oestradiol synthesis increased relative to oestrone synthesis in the 5-dayold neonate $\left(E_{1} / E_{2}=3.4\right)$ and still more at the stage of 14 days $\left(E_{1} / E_{2}=0 \cdot 78\right)$. FSH had no effect on oestrogen synthesis at the 4 stages investigated.
\end{abstract}

\section{Introduction}

While oestradiol is the main oestrogen produced by the ovary of the rabbit (Milewich et al., 1977) or human fetus (George \& Wilson, 1978), the ovary of the 19-20-day-old rat fetus forms almost exclusively oestrone (Weniger et al., 1984). We therefore investigated whether there was a shift from oestrone to oestradiol in more advanced fetal stages and neonates. In addition, since FSH stimulates markedly the aromatization of androgen by the granulosa cells of ovaries of 4-week old infantile rats (Moon et al., 1975; Dorrington et al., 1975; Erickson \& Hsueh, 1978), it was appropriate to investigate the effect of FSH on oestrogen synthesis by the neonatal ovary.

\section{Materials and Methods}

Rats of the Wistar strain, as well as Swiss mice, were used. Ovaries from 20- or 21-day-old rat fetuses or ovaries from neonates or infantile animals were cultured in vitro in Wolf \& Haffen's (1952) semi-solid medium or in Medium 199 with radiolabelled testosterone and in the presence or absence of FSH. Radiolabelled oestrone and oestradiol formed were determined by double isotopic dilution and recrystallization to constant specific activity.

Radioactive substrate and culture conditions. $\left[1,2,6,7-{ }^{3} \mathrm{H}\right]$ Testosterone (CEA, Gif-sur-Yvette, France), delivered in ethanol, was the radioactive substrate used. Its radiochemical purity, checked by thin-layer chromatography followed by radioactivity scanning, was $\geqslant 95 \%$; its specific activity at the time of use was $\sim 80 \mathrm{Ci} / \mathrm{mmol}$.

When using Wolff \& Haffen's (1952) culture method, an aliquant of the ethanolic $\left[{ }^{3} \mathrm{H}\right]$ testosterone solution was evaporated to dryness, and the residue was dissolved in a 1:3 (v/v) mixture of propane-1,2-diol and Tyrode's solution $\left(\mathrm{NaCl}, 8 \mathrm{~g} ; \mathrm{KCl}, 0.2 \mathrm{~g} ; \mathrm{CaCl}_{2}, 0.2 \mathrm{~g} ; \mathrm{MgCl}_{2} .6 \mathrm{H}_{2} \mathrm{O}, 0.1 \mathrm{~g} ; \mathrm{NaH}_{2} \mathrm{PO}_{4} \cdot \mathrm{H}_{2} \mathrm{O}, 0.05 \mathrm{~g} ; \mathrm{NaHCO}_{3}, 1 \mathrm{~g} ;\right.$ glucose, $1 \mathrm{~g} \mathrm{H}_{2} \mathrm{O}, 1 \mathrm{l}$ ). After explanting the ovaries, $2-5 \mu$ l of the radioactive solution containing FSH were dropped on the medium, and the ovaries were cultured at $37^{\circ} \mathrm{C}$ for $24 \mathrm{~h}$.

When ovaries were cultured in Medium 199, 1-2 $\mu$ l of the ethanolic $\left[{ }^{3} \mathrm{H}\right]$ testosterone solution were added directly to $0.1 \mathrm{ml}$ medium in a plastic Petri dish. Explants were placed on a Millipore filter $(0.22 \mu \mathrm{m}$ pore size $)$ supported by a stainless-steel grid. The incubation jar was gassed with $95 \% \mathrm{O}_{2}-5 \% \mathrm{CO}_{2}$. Depending on the age, 2-20 ovaries were cultured in one dish. The radioactive concentration and the molar concentration of $\left[{ }^{3} \mathrm{H}\right]$ testosterone in the culture medium in each experiment are shown in Table 2. Control experiments consisted of incubating media without tissue.

FSH preparation. The ovine follicle-stimulating hormone used was from NIH (NIH-FSH-S17). It was added to the medium at a concentration of $100 \mathrm{ng} / \mathrm{ml}$ or $5 \mu \mathrm{g} / \mathrm{ml}$. 
Extraction and chromatography. At the end of the $24 \mathrm{~h}$ culture period, one explant was taken for histological examination, whereas the media with all the other explants were analysed for the presence of oestrone and oestradiol formed from $\left[{ }^{3} \mathrm{H}\right]$ testosterone. To correct for possible analytical losses, $100 \mu \mathrm{g}$ of each of the radioinert compounds were added as carriers, as well as $\sim 7000$ c.p.m. of each of the ${ }^{14} \mathrm{C}$-labelled compounds (The Radiochemical Centre, Amersham, U.K.) as tracers.

Oestrogens are barely extractable from agar-agar-containing media after only mechanical dissociation (Akram \& Weniger, 1973), and so the media, with the carriers and tracers added, were first boiled with $15 \% \mathrm{HCl}$ under reflux for $1 \mathrm{~h}$ to obtain a homogeneous phase suitable for ether extraction. The 'hydrolysate' was brought to neutrality and extracted with diethyl ether. The ether extract was washed successively with a concentrated solution of $\mathrm{Na}_{2} \mathrm{CO}_{3}(\mathrm{pH}$ 10.5), a saturated solution of $\mathrm{NaHCO}_{3}$ and water. After evaporation of the ether, the dried residue was dissolved in a 1:1 (v/v) benzene-petroleum ether mixture, from which the oestrogens were extracted with $0.4 \mathrm{~N}-\mathrm{NaOH}$ and subjected to methylation with dimethyl sulphate (Brown, 1955). The methylated oestrogen fraction was chromatographed on a thin layer of silicagel HF $254+366$ (Merck, Darmstadt, F.R.G.) in chloroform-diethyl ether (9:1, v/v), which separates oestrone methyl ether and oestradiol methyl ether from one another. Carriers were viewed in u.v. light, scraped off and eluted. Oestradiol methyl ether was further purified by rechromatography in cyclohexane-ethyl acetate $(7: 3, \mathrm{v} / \mathrm{v})$; oestrone methyl ether was reduced to oestradiol methyl ether with sodium borohydride.

When tissue culture Medium 199 (Eurobio, Paris, France) was used, the extraction procedure was simplified: $\mathrm{N}-\mathrm{NaOH}$ was added to dissolve the explants. The $\mathrm{NaOH}$ solution was then made $0.4 \mathrm{~N}$, and the neutral steroids were extracted from this solution with benzene-petroleum ether $(1: 1, \mathrm{v} / \mathrm{v})$, before methylating the phenolic steroids, which remained in the alkaline phase, as above.

Recrystallization and specific activity determination. After adding $15 \mathrm{mg}$ of non-radioactive oestradiol methyl ether to the last eluate, repeated crystallizations were carried out in methanol-dichloromethane-petroleum ether (1:1:50, by vol.) or methanol-chloroform-petroleum ether (1:1:50, by vol.). Then I mg samples of the successive crystals and mother liquors were weighed on an ultramicrobalance. They were dissolved in toluene containing $4 \mathrm{~g}$ Scintimix 3 (Koch-Light, Colnbrook, U.K.) per litre, and the level of radioactivity was measured in a liquid scintillation spectrometer. The channels of the counter were windowed so that no ${ }^{3} \mathrm{H}$ passed into the ${ }^{14} \mathrm{C}$ channel: $12 \%$ of the ${ }^{14} \mathrm{C}$ passed into the ${ }^{3} \mathrm{H}$ channel and this value was subtracted from the radioactivity therein. Under these conditions, ${ }^{3} \mathrm{H}$ was counted with an efficiency of $33 \%$ and ${ }^{14} \mathrm{C}$ with an efficiency of $60 \%$. The background values were respectively 10 and 14 c.p.m.

The error of weighings was $\leqslant 1 \%$. Counting time was long enough to afford an error of $\leqslant 3 \%$. Under these conditions, the total error in specific activity determination was $\leqslant 4 \%$. Specific activity was considered constant whenever 3 successive crystallizations yielded values which were within $\pm 5 \%$ of the average (Axelrod et al., 1965).

Calculations. Specific activity determinations were relative to both ${ }^{14} \mathrm{C}$ and ${ }^{3} \mathrm{H}$. Knowing the exact amounts of ${ }^{14} \mathrm{C}$-labelled tracer and of ${ }^{3} \mathrm{H}$-labelled precursor added, the constant specific activity value relative to ${ }^{14} \mathrm{C}$ allowed the calculation of the recovery percentage, that relative to ${ }^{3} \mathrm{H}$ the calculation of the conversion percentage. Although ${ }^{3} \mathrm{H}$ in the $1 \beta$ and $2 \beta$ positions, which came to $7 \%$, was lost during aromatization, this loss was not taken into account when calculating the conversion percentage.

Table 1. Identification of oestrone and oestradiol by recrystallization to constant specific activity (c.p.m.) and calculation of the conversion percentage in Exp. 7

\begin{tabular}{|c|c|c|c|c|c|c|c|c|}
\hline \multirow[b]{3}{*}{ Crystallizations } & \multicolumn{4}{|c|}{ Oestrone } & \multicolumn{4}{|c|}{ Oestradiol } \\
\hline & \multicolumn{2}{|c|}{${ }^{14} \mathrm{C}$} & \multicolumn{2}{|c|}{${ }^{3} \mathrm{H}$} & \multicolumn{2}{|c|}{${ }^{14} \mathrm{C}$} & \multicolumn{2}{|c|}{${ }^{3} \mathrm{H}$} \\
\hline & Crystals & Liquor & Crystals & Liquor & Crystals & Liquor & Crystals & Liquor \\
\hline First & 178 & 222 & 106 & 114 & 193 & 226 & 39 & 64 \\
\hline $\begin{array}{l}\text { Second } \\
\text { Third } \\
\text { Fourth }\end{array}$ & $\begin{array}{l}172 \\
176 \\
176 \\
\end{array}$ & $\begin{array}{l}204 \\
181 \\
182\end{array}$ & $\begin{array}{l}103 \\
104 \\
104 \\
\end{array}$ & $\begin{array}{l}114 \\
113 \\
114\end{array}$ & $\begin{array}{l}177 \\
173 \\
176 \\
\end{array}$ & $\begin{array}{l}231 \\
187 \\
165\end{array}$ & $\begin{array}{l}37 \\
34 \\
35 \\
\end{array}$ & $\begin{array}{l}66 \\
36 \\
35\end{array}$ \\
\hline $\begin{array}{l}\text { Constant sp. act. } \\
\text { Constancy } \% \\
\text { Total activity }(\times 15) \\
\text { Starting activity } \\
\text { Recovery } \% \\
\text { Corrected }{ }^{3} \mathrm{H} \text { activity } \\
\text { Conversion } \%\end{array}$ & $\begin{array}{r}1 \\
26 \\
77\end{array}$ & $\begin{array}{l}5 \\
2 \cdot 6 \\
5 \\
0 \\
4\end{array}$ & $\begin{array}{r}15 \\
1513\end{array}$ & $\begin{array}{c}04 \\
0 \cdot 6 \\
60 \\
00\end{array}$ & $\begin{array}{r}17 \\
26 \\
70 \\
3\end{array}$ & $\begin{array}{l}5 \\
1 \cdot 3 \\
5 \\
0 \\
7 \cdot 5\end{array}$ & $\begin{array}{r}5 \\
1513\end{array}$ & $\begin{array}{l}35 \\
4 \cdot 8 \\
25 \\
00\end{array}$ \\
\hline
\end{tabular}




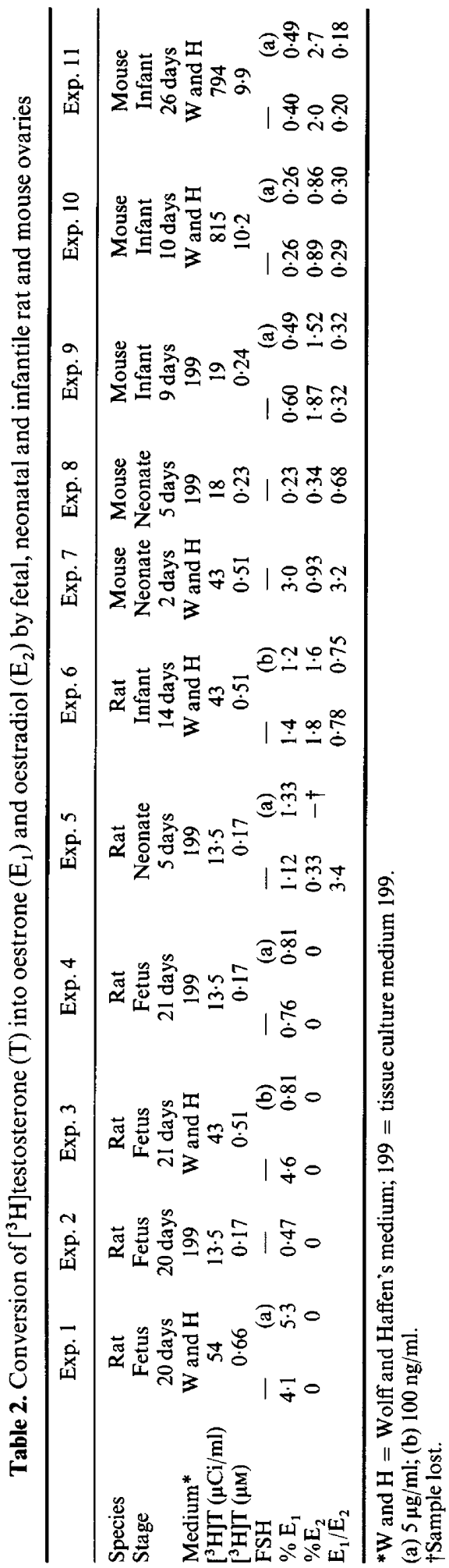




\section{Results}

Only media of ovaries in a healthy condition were analysed.

Table 1 gives examples of the identification of oestrone and oestradiol by recrystallization to constant specific activity and illustrates the way in which the conversion percentage was calculated. No oestrogens were found in control media incubated without tissue.

Table 2 summarizes the experimental conditions and lists the conversion percentages of $\left[{ }^{3} \mathrm{H}\right]$ testosterone into oestrone and oestradiol. Oestradiol was barely detectable at fetal stages. With advancing age, oestradiol secretion became more important than oestrone secretion. This is best illustrated with the mouse, for which the series is more complete. Mouse ovaries were preferred to rat ovaries for investigation of neonatal stages because their development is more rapid and, being smaller, they are easier to culture. Conversion percentages varied with the number of ovaries in culture and with the amount of radioactive substrate added, but at comparable stages, the oestrone: oestradiol ratio was constant (see Exps 5 and 7 or 9 and 10). Conversion percentages were higher in some experiments when FSH was added to the culture medium. However, the increase was slight, amounting to $50 \%$ at most. Because of the many steps in the experimental procedure, this slight, sporadic increase was not considered to be significant.

\section{Discussion}

Moon et al. (1975) showed that ovaries from 28-day-old hypophysectomized rats cultured in Medium 199 released oestradiol into the culture medium. The addition of testosterone was virtually without effect, although FSH produced a 2-3-fold increase in oestradiol secretion. In the presence of $0.5 \mu \mathrm{M}$-testosterone as substrate, FSH had a still greater effect and enhanced oestradiol production 8-10 times. It was concluded that FSH stimulated aromatization.

In subsequent experiments, Dorrington et al. (1975) showed that granulosa cells isolated from the ovaries of hypophysectomized 29-day-old rats secreted only negligible quantities of oestradiol in the absence of both testosterone and FSH. The addition of testosterone or FSH separately to the culture medium did not influence the production of oestradiol. However, the addition of both substances greatly enhanced oestradiol secretion. Oestrone was also produced but at levels only $10-30 \%$ as high as oestradiol. It was concluded that granulosa cells needed androgen precursors provided by theca and/or interstitial cells. When these androgen precursors are present, FSH stimulates specifically the aromatizing enzyme system in granulosa cells.

The results of Dorrington et al. (1975) were confirmed by Erickson \& Hsueh (1978). In the absence of androstenedione as substrate, no significant stimulation of oestrogen secretion was observed in FSH-treated granulosa cell cultures. However, in the presence of androstenedione, FSH stimulated oestrogen production 9- and 40-fold after 1 and 2 days, respectively.

Funkenstein \& Nimrod (1983) studied the steroidogenic abilities of 4-day-old rat ovaries in organ culture. In the presence of $3 \mu \mathrm{M}$-testosterone, there was a significant oestradiol production, which increased 4 times when dibutyryl cyclic AMP was added to the medium. Oestrone was not measured.

Milewich et al. (1977) studied oestrogen formation by the fetal ovaries of rabbits: the conversion percentages of $0 \cdot 5 \mu \mathrm{M}-\left[{ }^{3} \mathrm{H}\right]$ testosterone or $\left[{ }^{3} \mathrm{H}\right]$ androstenedione to oestrone and oestradiol by the 19-day-old ovary in vitro were determined. The ratios of oestradiol to oestrone formed were 15 and 7.5 from testosterone and androstenedione, respectively.

Using the same methods, George \& Wilson (1978) found that the ovary of the human fetus of $12.5-13.8 \mathrm{~cm}$ crown-rump length also formed more oestradiol than oestrone, the ratio being $\sim 2$ with androstenedione as the substrate and 8 with testosterone as the substrate.

Appreciable amounts of oestrone were formed by the 19-20-day-old fetal rat ovary from testosterone or progesterone even in the absence of FSH; virtually no oestradiol was formed (Weniger $e t$ al., 1984). When FSH was added to the cultures, there was no stimulatory effect on the conversion 
of progesterone, dehydroepiandrosterone, testosterone or androstenedione into oestrogens (Weniger et al., 1985).

In the present study, which tried to establish a link between fetal and infantile stages, the oestrone:oestradiol ratio was found to diminish with increasing age. Negligible at fetal stages of 20 or 21 days, oestradiol synthesis had superseded oestrone synthesis by 14 days after birth. This result is in keeping with the finding of Dorrington et al. (1975) that the production of oestradiol was 3-10 times as high as that of oestrone in the 29-day-old prepubertal rat.

The absence of an effect of FSH in the present study poses a problem. According to Picon et al. (1985), FSH stimulated total oestrogen production by the rat ovary 2-fold at the fetal stage of 20 days and 1-7-fold at 4 days after birth. In the mouse, FSH increased oestrogen production by the ovary 7-, 6- and 10-fold respectively at 3, 6 and 9 days after birth (Terada et al., 1984). In our experiments, oestrogen production was higher in the presence of FSH than in its absence in 5 cultures (1.5-fold at the best), lower in 2 cultures and equal in 1 culture. These variations are considered to arise from unequal experimental conditions. In our opinion, augmentation of oestrogen secretion in the presence of FSH should be observed in all cultures and be at least 2-fold to be considered significant. The discrepancy between the results of Picon et al. (1985) and Terada et al. (1984) and ours cannot be explained. Perhaps one should look for the presence of FSH receptors.

The physiological significance of oestrogen secretion by the fetal and neonatal ovary is not known. There is no role for the ovary in female sex differentiation, as shown by Jost's (1946-47) castration experiments.

In conclusion, for the time being, the fetal rat ovary is unique as regards the prevalence of the formation of oestrone over that of oestradiol. As puberty is approached, oestradiol secretion becomes more important. More work will have to be done to get a clear picture of the effect of FSH on aromatase activity.

\section{References}

Akram, H. \& Weniger, J.-P. (1973) Effet de l'hypophysectomie sur la sécrétion d'oestrogènes par les gonades de l'embryon de Canard femelle. Gen. comp. Endocrin. 21, 543-546.

Axelrod, L.R., Matthijssen, C., Goldzieher, J.W. \& Pulliam, J.E. (1965) Definitive identification of microquantities of radioactive steroids by recrystallization to constant specific activity. Acta endocr., Copenh., Suppl. 99, 7-66.

Brown, J.B. (1955) A chemical method for the determination of oestriol, oestrone and oestradiol in human urine. Biochem. J. 60, 185-193.

Dorrington, J.H., Moon, Y.S. \& Armstrong, D.T. (1975) Estradiol- $17 \beta$ biosynthesis in cultured granulosa cells from hypophysectomized immature rats: stimulation by follicle-stimulating hormone. Endocrinology. 97, 1328-1331.

Erickson, G.F. \& Hsueh, A.J.W. (1978) Stimulation of aromatase activity by follicle stimulating hormone in rat granulosa cells in vivo and in vitro. Endocrinology 102, 1275-1282.

George, F.W. \& Wilson, J.D. (1978) Conversion of androgen to estrogen by the human fetal ovary. $J$. Clin. Endocr. Metab. 47, 550-555.

Funkenstein, B. \& Nimrod, A. (1983) The dynamics of activation of steroidogenic pathways in cultured neonatal rat ovaries. J. Steroid Biochem. 18, 353-356.

Jost, A. (1946-1947) Recherches sur la différenciation sexuelle de l'embryon de Lapin. III. Rôle des gonades foetales dans la différenciation sexuelle somatique. Archs Anat. microsc. Morph. exp. 36, 271-315.
Milewich, L., George, F.W. \& Wilson, J.D. (1977) Estrogen formation by the ovary of the rabbit embryo. Endocrinology. 100, 187-196.

Moon, Y.S., Dorrington, J.H. \& Armstrong, D.T. (1975) Stimulatory action of follicle-stimulating hormone on estradiol-17 $\beta$ secretion by hypophysectomized rat ovaries in organ culture. Endocrinology. 97, 244-247.

Picon, R., Pelloux, M.C., Benhaïm, A. \& Gloaguen, F. (1985) Conversion of androgen to estrogen by the rat fetal and neonatal female gonad:effects of dcAMP and FSH. J. Steroid Biochem. 23, 995-1000.

Terada, N., Kuroda, H., Namiki, M., Kitamura, Y. \& Matsumoto, K. (1984) Augmentation of aromatase activity by $\mathrm{FSH}$ in ovaries of fetal and neonatal mice in organ culture. J. Steroid Biochem. 20, 741-745.

Weniger, J.-P., Chouraqui, J. \& A. Zeis (1984) Conversion of testosterone to oestrone by the ovary of the rat embryo in organ culture. J. Steroid Biochem. 21, 347-349.

Weniger, J.-P., Chouraqui, J. \& Zeis, A. (1985) Steroid conversions by the 19-day-old foetal rat ovary in organ culture. Biol. Chem. Hoppe-Seyler 366, $555-559$.

Wolff, E. \& Hafien, K. (1952) Sur le développement et la différenciation sexuelle des gonades embryonnaires d'Oiseau en culture in vitro. J. exp. Zool. 119, 381-399. 